\title{
Quality of Melon 'UFERSA-05 var. ACIDULUS and Pele de Sapo "Mabel" Minimally Processed, Kept in Different Packages
}

\author{
Maria Luiza Pereira de Araújo, Fanquiele Ribeiro de Oliveira', \\ Marianne Lima Barboza1, Glauber Enrique Souza Nunes', \\ Pahlevi Augusto de Souza ${ }^{3}$, Adriano do Nascimento Simões ${ }^{{ }^{*}}$ \\ ${ }^{1}$ Unidade Acadêmica de Serra Talhada, Universidade Federal Rural de Pernambuco, Serra Talhada, Brazil \\ ${ }^{2}$ Departamento de Ciências Vegetais, UFERSA, Mossoró, Brazil \\ ${ }^{3}$ Instituto Federal de Educação, Ciência e Tecnologia do Ceará, Limoeiro do Norte, Brazil \\ Email: ${ }^{\text {adriano@uast.ufrpe.br }}$
}

Received 27 October 2013; revised 27 November 2013; accepted 4 December 2013

Copyright (C) 2014 by authors and Scientific Research Publishing Inc.

This work is licensed under the Creative Commons Attribution International License (CC BY). http://creativecommons.org/licenses/by/4.0/

(c) (7) Open Access

\section{Abstract}

This study aimed at evaluating the quality of melon Pele de Sapo "Mabel" and Yellow melon "UFERSA-05" minimally processed preserved in different packages. The fruits were harvested at Mossoró-RN and transported to Serra Talhada-PE. In the first study, melon fruit Piel de Sapo "Mabel" was selected, washed, weighed, cooled, peeled, cut into cube shape, sanitized in chlorine solution, drained, packaged in rigid polypropylene tray, sealed with polypropylene film or polypropylene rigid cap and kept for 8 days at $8^{\circ} \mathrm{C}$. In the second study, fruits of yellow melon "UFERSA-05" and Pele de Sapo "Mabel" were minimally processed and kept in rigid polypropylene tray, sealed with polypropylene film and stored for 8 days at $8^{\circ} \mathrm{C}$. There was no significant interaction between packaging (sealed with film and polypropylene cover) and period of conservation, for $\mathrm{pH}$, total titratable acidity (TTA), total soluble solids (TSS) and Loss of fresh mass (LFM) for Melon "Mabel". While there was significant interaction between types of melon ("UFERSA-05" and "Mabel") and storage period $(0,2,4,6$, and 8 days) for $\mathrm{pH}$, TTA and TSS. In sensory evaluation were noticeable changes in appearance, flavor, aroma and flesh firmness, characterized by translucency, alcoholic aroma and softening in "Mabel" melon kept in tray with lid. Melon "UFERSA-05" showed lower pH, total soluble solids, total soluble sugars, PME activity, lack of translucency high flesh firmness compared to "Mabel" melon during storage. The high levels of sugars in melon "Mabel" may be related to the incidence of translucency, which was not observed in "UFERSA-05" melon, with a strong potential to minimal processing.

\footnotetext{
${ }^{*}$ Corresponding author.
} 


\section{Keywords}

\section{Cucumis melo; Translucency; Pectin Methylesterase; Total Soluble Sugars}

\section{Introduction}

Melon is a crop of great global importance. Its production in Brazil reached approximately 478,431 tons in 2010 [1]. Yellow and Pele de Sapo are highlighted, belonging to the group Inodorus, showing high expression in Brazilian exports [2].

The melon has great potential to minimal processing, due to its appreciable features of flavor, aroma and appearance, as well as high resistance in postharvest. The handling resistance, appearance, flavor and acceptability are often influenced by firmness and total sugars. The softening of minimally-processed fruits during storage is usually accompanied by degradation of the middle lamella and loss of cell adhesion [3]. This process derives from the pectin solubilization of cell wall involving the action of cell wall hydrolytic enzymes, such as polygalacturonase (PG, EC 3.2.1.15) and pectin methylesterase (PME, EC 3.1.1.11) [3]. The flavor is directly connected mainly to the content of total soluble sugars [4].

Surveys show the use of melon, Cantaloupe type [5], "Orange Flesh” [6] [7] and Inodorus: Yellow [8] [9], Pele de Sapo [10] among others in the minimal processing.

Minimally processed melon has a series of physiological changes that are inducers of product depreciation during storage, such as increased respiration, ethylene production, reduction of flesh firmness, aroma alcoholic, the translucency and microbiological contamination [5] [10] [11].

The translucency is one of the visual problems in minimally processed melon. This characteristic tends to increase during storage [5] and is characterized as a transparent appearance which begins at the edges of melon, with a loss of turgor. Some studies have linked the occurrence of translucency to the content of total soluble sugars and loss of membrane integrity, as measured by electrolyte leakage [12] [13]. It may be linked to damage by mechanical stress and temperature [5] [11].

The adequacy of packaging more suited to minimal processing is devices that can be used to extend the shelflife of minimally processed melon. Several packages have been used for preservation of minimally processed melon, such as low density polyethylene film (LDPE), polypropylene film (PP), rigid packaging of polyethylene terephthalate (PET), micro perforated polypropylene film (MPP), bioriented polypropylene film (BPP) and oriented polypropylene film (OPP) [11] [14]. However, all packages studied were used in commercial melon genotypes such as Galia (cv. Bonus Gredos and II), Cantaloupe (cv. Dalton), Yellow (cv. Solaris), Pele de Sapo (cv. Sancho) [11] [14] among others.

In studies conducted at the Universidade Federal Rural do Semiárido (UFERSA), Mossoró-RN, the genotype of melon called 'UFERSA-05 var. Acidulus has been developed which exhibits high flesh firmness after several days of storage at room temperature $\left( \pm 29^{\circ} \mathrm{C}\right)$. There are no works on the postharvest behavior of this fruit, even on minimal processing. It is believed that this melon in minimally processed form and associated with appropriate packaging can maintain the quality for longer compared to the melon traditionally been marketed.

Thus, this study aimed at evaluating the quality of melon 'UFERSA-05 var. ACIDULUS and Pele de Sapo "Mabel" minimally processed, stored at $5^{\circ} \mathrm{C}$ in different packagings.

\section{Material and Methods}

\subsection{Obtaining Fruits and Minimal Processing}

Fruits of Pele de Sapo "Mabel” and Yellow 'UFERSA-05 var. ACIDULUS melons were obtained from contiguous crops conducted under the same soil conditions and cultural practices in the Department of Plant Sciences, Universidade Federal Rural do Semiárido (UFERSA), Mossoró (RN). They were transported to the Academic Unit of Serra Talhada (PE), subsequently washed in tap water and kept in cold storage chamber at $8^{\circ} \mathrm{C} \pm 2^{\circ} \mathrm{C}$ for $24 \mathrm{~h}$ and $90 \% \pm 5 \% \mathrm{RH}$.

After this period, the fruits of melon, 'UFERSA-05 var. ACIDULUS and "Mabel" were weighed and minimally processed according to [14]. Whole fruits were sanitized using chlorine solution (Dichloroisocyanurate so- 
dium dihydrate) at $100 \mathrm{mg} \mathrm{L}^{-1}$ of active chlorine for 10 minutes. They were peeled, sliced and cut into cubes of approximately $18 \mathrm{~cm}^{3}$ with the aid of stainless steel knives. The samples were immersed in chloride solution at $100 \mathrm{mg} \mathrm{L}^{-1}$ for three seconds in water at $\pm 5^{\circ} \mathrm{C}$, followed by immersion in water $\pm 5^{\circ} \mathrm{C}$ for three seconds and drained for 10 seconds.

\subsection{Package Evaluation in Minimally Processed Melon "Mabel” Var. Acidulus}

About eight cubes of minimally processed melon Pele de Sapo "Mabel" were kept in rigid polypropylene trays of $145 \times 100 \times 50 \mathrm{~mm}$ (length, width and height, respectively). The trays containing melon cubes were weighed and then sealed with polypropylene film (PP) of $150 \mathrm{~mm} \times 200$ and $0.6 \mu \mathrm{m}$ (height, width and thickness, respectively) or with rigid lid of polypropylene. Trays with fruits were kept for eight days at $8^{\circ} \mathrm{C} \pm 2^{\circ} \mathrm{C}$ and $90 \% \pm 5 \% \mathrm{RH}$.

\subsection{Evaluation of the Quality of Minimally Processed Melon 'UFERSA-05 Var. ACIDULUS and "Mabel"}

The second study evaluated the quality of minimally processed melon 'UFERSA-05 var. ACIDULUS and "Mabel”, packed with about eight cubes in polypropylene trays $(145 \times 100 \times 50 \mathrm{~mm}$, length, width and height, respectively), sealed with polypropylene film of $0.6 \mu \mathrm{m}$ (thickness) and retained for eight days at $8^{\circ} \mathrm{C} \pm 2^{\circ} \mathrm{C}$ and $90 \% \pm 5 \%$ RH.

\subsection{Evaluations Physico-Chemical and Biochemical}

The analyses in both experiments were carried out every two days for eight days.

It was evaluated the $\mathrm{pH}$, measured directly from the cell juice with the use of a pH meter (LUTROM).

Total titratable acidity (TTA) was determined by titration, using $10 \mathrm{ml}$ of cell juice, $5 \mathrm{~mL}$ of distilled water and three drops of phenolphthalein (1\%). This mixture was titrated with sodium hydroxide $(\mathrm{NaOH})$ to $0.1 \mathrm{~N}$. To calculate the percentage (\%) of citric acid was used the following equation: TTA $(\%)=(\mathrm{Vb} * \mathrm{Nb} * \mathrm{fb} * \mathrm{fa} * \mathrm{fd} *$ 100/V sample), where: $\mathrm{Vb}=\mathrm{NaOH}$ volume spent; $\mathrm{Nb}=\mathrm{NaOH}$ concentration; $\mathrm{fb}=\mathrm{NaOH}$ factor; fa $=$ alkali acid factor; $\mathrm{fd}=$ dilution factor e $\mathrm{V}=$ juice volume.

The total soluble solids (TSS) were measured using a bench type ABBE refractometer after added drops of filtered juice, with the result expressed in \%.

Loss of fresh mass was obtained by the percentage ratio of mass values weighted in BEL MARK semi- analytical scale at baseline (day 0 ) and at each valuation date.

For the analysis of total soluble sugars (TSS) and pectin methyl esterase (PME), minimally processed cubes of melon crushed in food multiprocessor and transferred to a closed container and frozen at approximately $20^{\circ} \mathrm{C}$ until the analyses.

The soluble sugars were determined by the method of Antrona [15]. One aliquot of $100 \mu \mathrm{L}$ was removed from melon juice filtered and the volume was completed to $100 \mathrm{~mL}$ and $200 \mathrm{~mL}$ with distilled water for melon 'UFERSA-05 var. Acidulus and "Mabel", respectively. 1000- $\mu \mathrm{L}$ aliquot of the extract was added to the test tube and $2000 \mu \mathrm{L}$ of anthrone reagent (200 mg anthrone to $100 \mathrm{~mL}$ sulfuric acid PA). The tubes were sealed, shaken and subjected to bath in boiling water for eight minutes, followed by cooling in ice water. Subsequently, the reading on spectrophotometer wad performed at $620 \mathrm{~nm}$ wavelength.

For testing and extraction of PME was used about $2.5 \mathrm{~g}$ of melon sample homogenized in $10 \mathrm{~mL}$ of $0.2 \mathrm{~N}$ $\mathrm{NaCl}$ solution forming an enzymatic extract. Next, $5 \mathrm{~mL}$ of enzyme extract was added to $30 \mathrm{~mL}$ of $1 \%$ citrus pectin solution ( $1 \mathrm{~g}$ citrus pectin in $100 \mathrm{~mL}$ of $0.2 \mathrm{~N} \mathrm{NaCl})$. The mixture was adjusted to $\mathrm{pH} 7.0$ with $\mathrm{NaOH}(0.1$ $\mathrm{N})$ under magnetic stirring. The titration with $\mathrm{NaOH}(0.01 \mathrm{~N})$ was performed for 10 minutes. The PME activity was determined by titration using the methodology described by [16]. The unit of PME was defined as the amount of enzyme capable of catalyzing the demethylation of pectin corresponding to the consumption of one $\mathrm{NaOH} \mathrm{nmol} \mathrm{min}^{-1} \cdot \mathrm{g}^{-1}$ of fresh tissue.

The sensory evaluation was performed by a subjective scale of scores based on the evaluation criteria adopted by [14], considering the characteristics: aroma, appearance, flavor and pulp flesh firmness. The scores adopted were from 5 to 2, corresponding respectively to: $5=$ excellent, $4=$ good, $3=$ regular, 2 = bad. The score descriptions for each item include: Aroma: 5-aromatic melon; 4-mild aroma; 3-no aroma, 2-alcoholic aroma. Appearance: 5-melon with appearance of freshness; 4-moderate fresh appearance; 3-a little fresh appearance and beginning of translucency; 2 -no fresh appearance and high translucency. Flavor: 5-melon with cha- 
racteristic flavor; 4-slight loss of flavor; 3-absence of flavor; 2-alcoholic flavor. Flesh Firmness: 5-firm melon; 4-firmly but mild modesty; 3-loss of firmness; 2-lack of firmness.

\subsection{Statistical Analysis}

The experiments were conducted in a completely randomized design (CRD) in factorial arrangement with three replicates of a pack per plot. In the first study with the hybrid Mabel var. ACIDULUS was used the $2 \times 4$ factorial design, with the first factor consisting of types of packaging used (rigid polypropylene tray sealed with polypropylene film with $0.6 \mu \mathrm{m}$ or rigid polypropylene tray sealed with the cap) and the second being the storage time (0, 4, 6 and 8 days). In the second study, we used the $5 \times 2$ factorial design, with the first factor consisting of genotypes ('UFERSA-05 var. ACIDULUS and "Mabel") and the second factor consisted of the storage time (0, 2, 4, 6 and 8 days). The data significance was determined by the t-test at $5 \%$ probability isong the software ASSISTAT for means comparison. The results corresponding to total soluble sugars, pectin methylesterase and sensory analysis were used with standard deviation. Some results were also presented the standard deviation.

\section{Results and Discussion}

The whole melons are minimally processed and presented in Figure 1.

There was decrease in the content of total soluble sugars in minimally processed melon "Mabel" during storage in two packages studied (Figure 2). The reduction in the content of total soluble sugars in this study is probably due to the use of sugars as substrates in fruit respiration [17].

There was increase in the PME activity, intensified from the sixth day in minimally processed melon "Mabel" during storage in both packages studied (Figure 2(b)). In melon, substantial depolymerization and solubilization of pectin occur during ripening [18]. The degradation of pectin mediated by Polygalacturonase (PG) occurs after the initial stages of fruit softening and probably contributes significantly to the excessive ripening stages including softening and deterioration [19]. The reduction in the degree of esterification of the pectin observed during the ripening of fruits has been associated to the desterifying action of pectin methyl esterase (PME) that determines the rate and extent of hydrolysis of the pectic substances by the polygalacturonase (PG), which normally leads to increased solubility and softening of pectin fruits [20]. These same authors studying the changes of cell wall components of "Orange Flesh melon", verified a clear reduction in the degree of esterification during storage not affirming that this effect was caused by the presence of the PME. Furthermore, [6] found no increased PME activity and PG in minimally processed "Orange Flesh" melon, kept on modified atmosphere under refrigeration at $6^{\circ} \mathrm{C}$.

The subjective scores of external appearance, aroma, flavor and flesh firmness of the minimally processed melon "Mabel" in both packages reduced over the period of conservation (Figures 3(a)-(d)). It was noted that in the melon "Mabel" packed in sealed polypropylene rigid tray with cover, after six days of storage, all parameters described had mean scores equal to three, considered acceptance limit (Figures 3(a)-(d)). Unlike melon kept in the tray sealed with polypropylene film, wherein the score three, was obtained after eight days of storage for all evaluations (Figures 3(a)-(d)).

The marked changes in the minimally processed melon "Mabel", which contributed to the scores reduction, more evident on the pieces kept packed in tray with lid included: the translucency, alcoholic flavor and softening, while not having been made instrumental analysis, these characteristics were perceived by the sensory panel. The perception of alcoholic flavor may have occurred because of the high barrier of $\mathrm{O}_{2}$ which the cover promotes. While softening may have been due to a small difference, although not significant, in the PME activity from 4 days in the fruits sealed with a lid (Figure 2(b)).

Overall, the differences were minimal for titrable total acidity, $\mathrm{pH}$, total soluble solids, mass loss, total soluble sugars and PME activity in minimally processed melon "Mabel” and conserved in packages with lid or PP film. However, the conservation was inductive of loss of total soluble sugars and increase in PME activity, especially in melon packed with the lid. This may be associated with the perception of alcoholic flavor perceived by the sensory panel. These results will serve as a basis for using the PP film in subsequent works.

Evaluating the quality of minimally processed melons 'UFERSA-05 var. Acidulus and "Mabel” kept in rigid polypropylene tray sealed with polypropylene film $0.6 \mu \mathrm{m}$ thick, there was significant interaction between types of melon ('UFERSA-05 var. Acidulus and "Mabel") and storage time (0, 2, 4, 6, and 8 days) for pH, titratable 

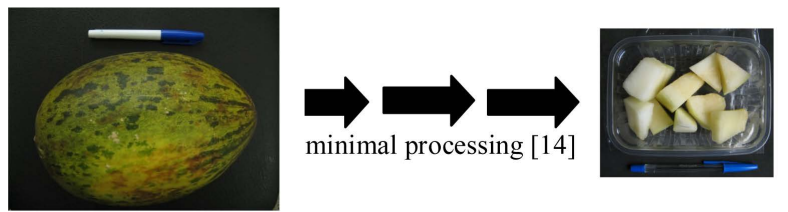

Pele de Sapo 'Mabel'
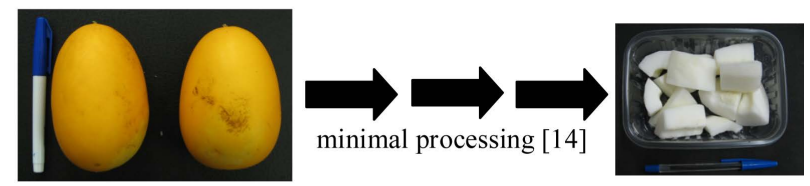

'UFERSA-05 var. ACIDULUS

Figure 1. Pele de Sapo "Mabel” and yellow 'UFERSA-05 var. ACIDULUS melon whole and after minimal proces.

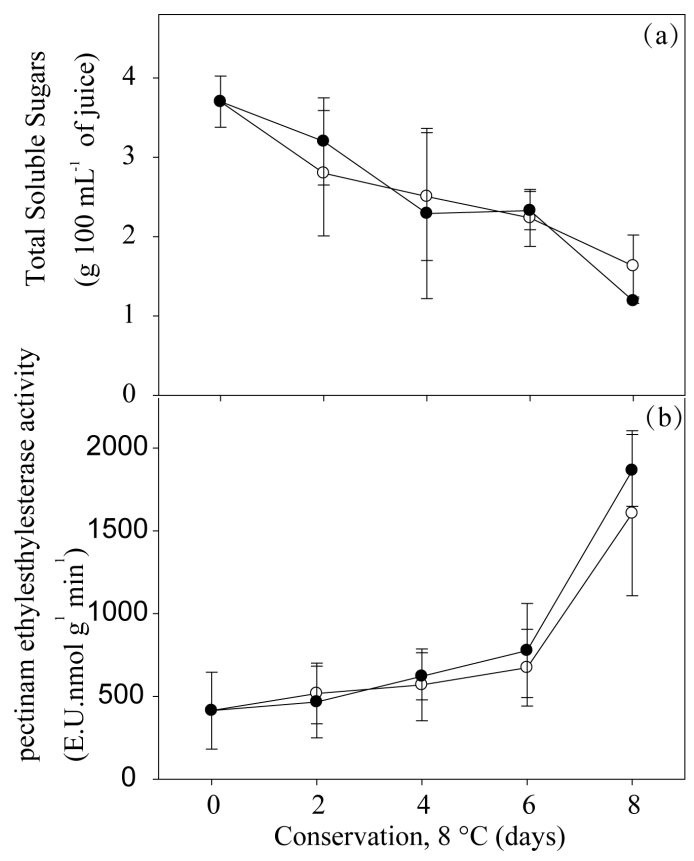

Figure 2. Total Soluble Sugars (A) and Pectinamethylesterase activity, PME (B) in Pele of Sapo "Mabel" melon, minimally processed stored in two types of packaging: rigid tray polypropylene sealed with lid (-๑-), or polypropylene film (-०-), under refrigeration $\left(8^{\circ} \mathrm{C} \pm 2^{\circ} \mathrm{C}\right.$ and $\left.90 \% \pm 5 \% \mathrm{RU}\right)$ for 8 days. Serra Talhada-PE, UFRPE/UAST, 2012.

acidity (TA) and total soluble solids (TSS). For Loss of fresh mass (LFM) there was no interaction between the factors studied, reason why the results are not shown; the weight loss in both genotypes, 'UFERSA-05 var. ACIDULUS and "Mabel", was minimal after eight days of storage (data not shown). The dehydration did not affect the appearance during the period studied. Therefore, the polypropylene package used was effective as a barrier for water vapor diffusion to minimally processed melon.

The values of $\mathrm{pH}$ and titratable total acidity, represented by citric acid and total soluble solids, remained slightly constant throughout days of storage for both genotypes (Figures 4(a)-(c)). The melon 'UFERSA-05 var. ACIDULUS showed lower pH, TSS and total soluble sugars (TSA) than the "Mabel" melon (Figures 4(c) and (d)). The content of total soluble sugars decreased for both genotypes, particularly for minimally processed Melon "Mabel” during storage (Figure 4(d)). 


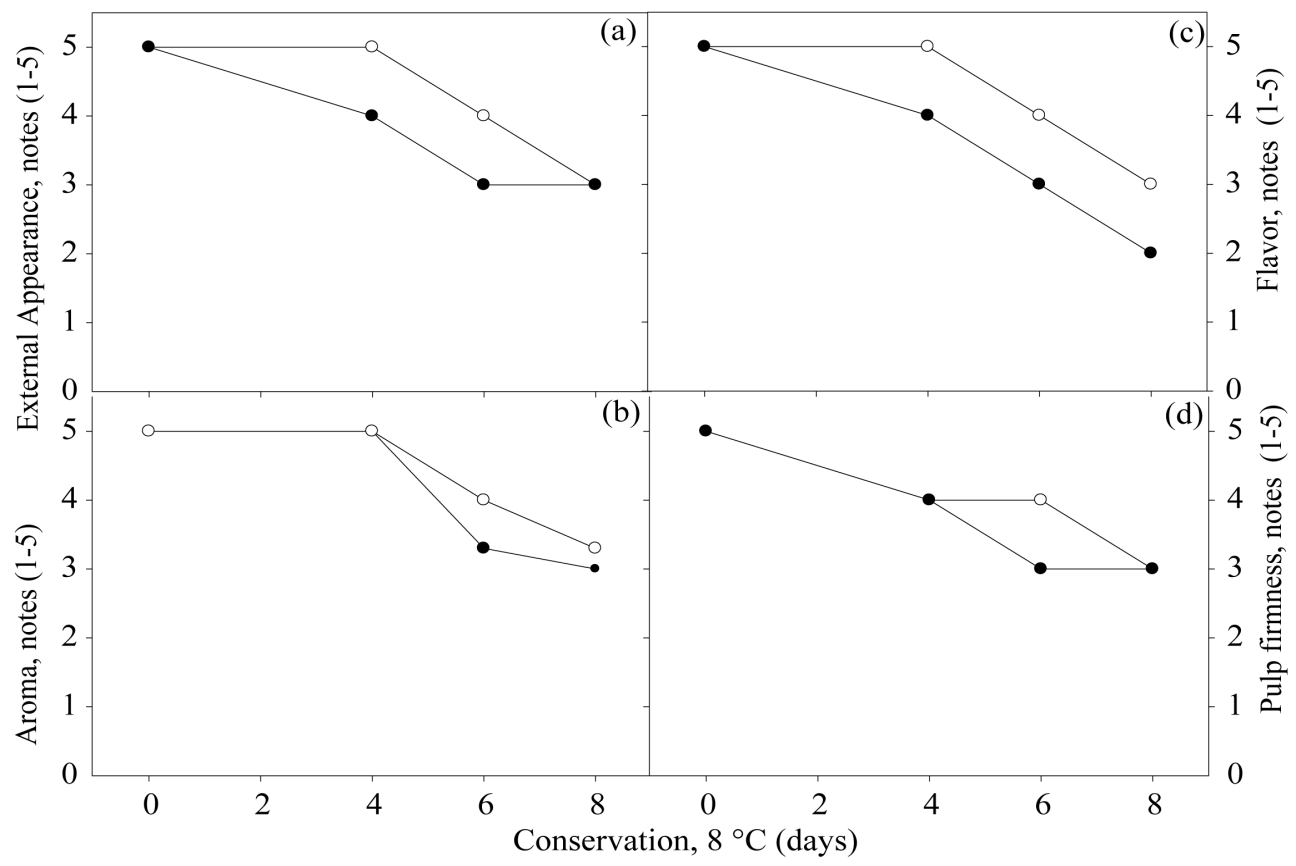

Figure 3. External Appearance scores (a), Aroma (b), Flavour (c) and Flesh Firmness (d) Pele of Sapo "Mabel” melon minimally processed and packaged at $8^{\circ} \mathrm{C} \pm 2{ }^{\circ} \mathrm{C}$ for 8 days in two types of packaging: rigid polypropylene tray sealed with polypropylene film $0.6 \mu \mathrm{m}$ thickness (-o-) and rigid tray sealed with polypropylene lid (-๑-). Horizontal discontinuous lines indicate the limit of acceptance from the consumer point of view. Serra Talhada-PE, UFRPE/UAST, 2012.

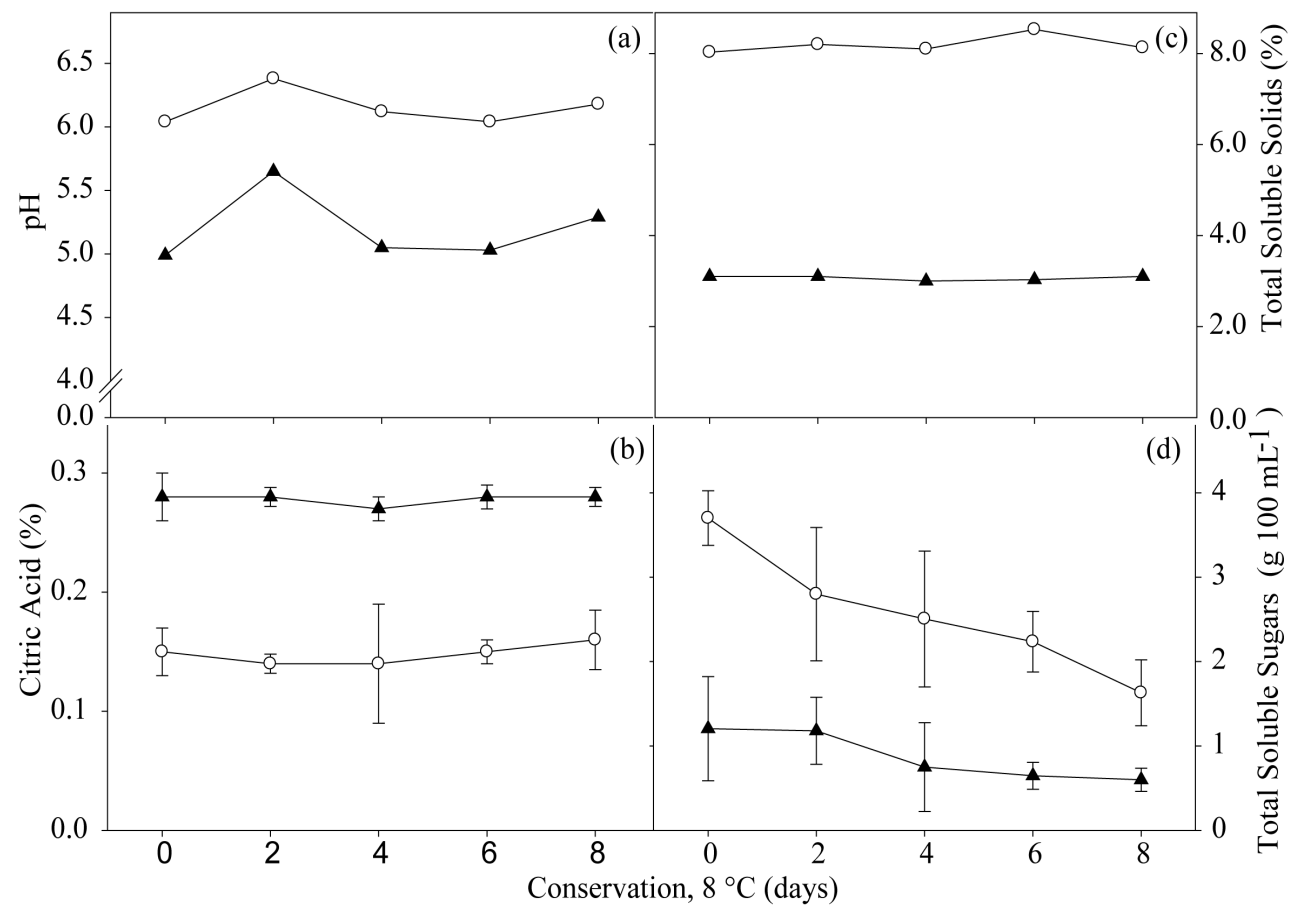

Figure 4. pH (a), Titratable acidity (\% Citric Acid) (b), Total Soluble Solids (c) and Total Soluble Sugars (d), in genotypes Yellow "UFERSA-05" var. ACIDULUS (- $\mathbf{-}-)$ and Pele of Sapo "Mabel” melon (-०-) minimally processed, keep in tray of PP sealed with polypropylene film at $8^{\circ} \mathrm{C} \pm 2{ }^{\circ} \mathrm{C}$ for 8 days. Values are the mean of three replicates and error bars represent the standard deviation. Serra Talhada-PE, UFRPE/UAST, 2012. 
Possibly, the TSS reduction is related to a higher energy demand depending on the injuries caused to the plant tissue, increased by conservation to $8^{\circ} \mathrm{C}$. For minimally processed "Orange Flesh" melon stored at $6^{\circ} \mathrm{C}$, the content of TSS remained relatively constant over conservation [6].

The high TTA, low content of soluble solids and TSS, checked in Melon 'UFERSA-05 var. Acidulus (Figures 4(b)-(d)) must be related to a lack of sweetness. Furthermore, according to [21], fruits that exhibit translucency showed increased $\mathrm{pH}$, TSS, TTA and TSA. In the present study, the fruits of "Mabel" had higher sugar content, being also susceptible to translucency compared to the melon 'UFERSA-05 var. ACIDULUS and can the translucency be related to high levels of sugars, as observed in pineapple [12] in which these authors also relate such disorder to the increased activity of cell wall invertase, in which is promoted the accumulation of sucrose in the apoplast, followed by reduction in the potential of solute and consequent increase in the volume of water in the apoplast, causing translucency.

With respect to sensory evaluation, there was reduction in the subjective scores for external appearance, aroma, flavor and flesh firmness for both genotypes, depending on conservation days studied (Figures 5(a)-(d)).

At eight days of storage the aroma of melon 'UFERSA-05 var. Acidulus showed maximum score, and the other attributes, score 4. The melon "Mabel" showed score three in this period, limit of acceptability, for all traits studied (Figures 5(a)-(d)). In the melon "Mabel", the reduction in external appearance, aroma and flavor was compromised by the presence of translucency and flavor loss (Figures 4(a)-(c)). This may be associated with TSS decline (Figure 4(d)).

The reduction of flesh firmness was more noticeable by the sensory panel on the melon "Mabel" from the fourth day with reduction to four (Figure 5(d)). On the eighth day the score for flesh firmness was corresponding to the acceptance limit (Figure 5(d)). For Melon 'UFERSA-05 var. Acidulus values of flesh firmness reduced only on the sixth day, remaining until the end of the study (Figure 5(d)). These results may be related to higher values in PME activity in melon "Mabel" (Figure 6).

\section{Conclusion}

Conservation of minimally processed "Mabel" melon was more suitable for rigid polypropylene tray sealed with polypropylene film $0.6 \mu \mathrm{m}$ thick. The Melon 'UFERSA-05 var. ACIDULUS proved suitable for use in minimum

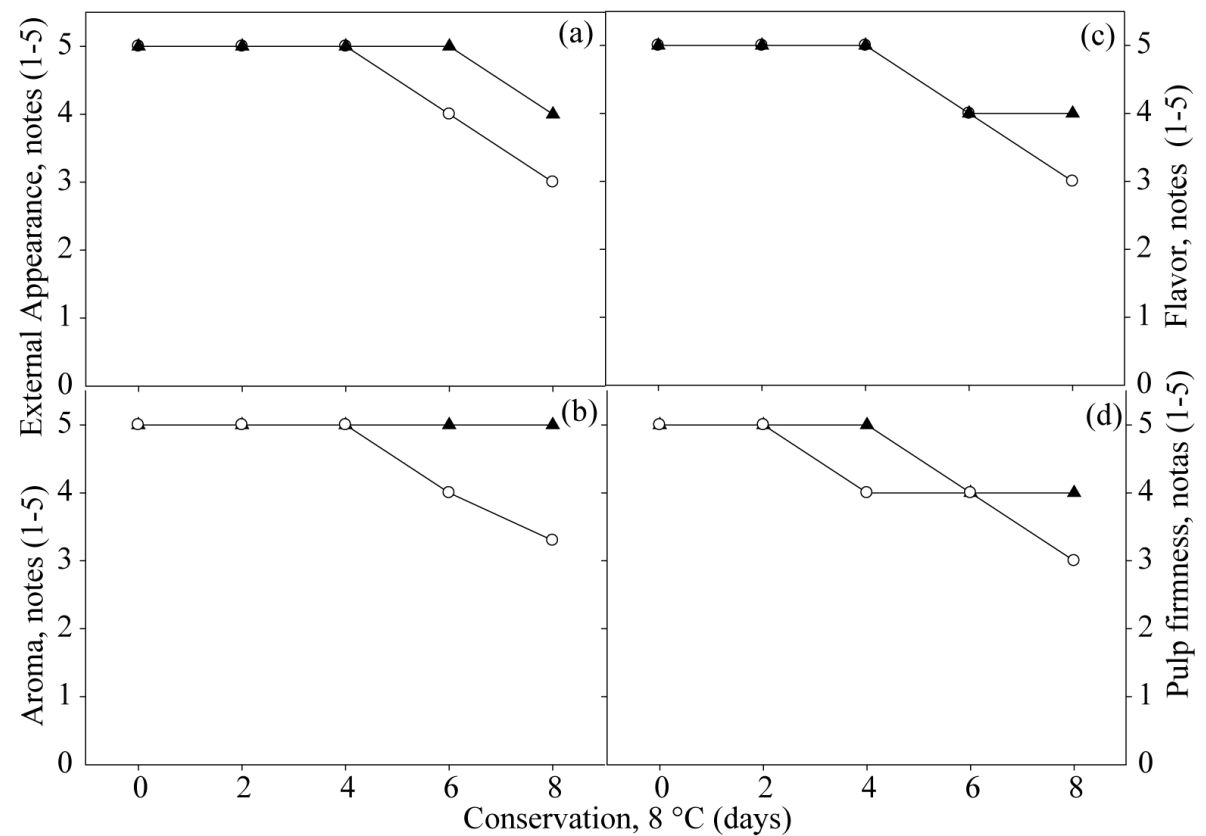

Figure 5. External Appearance score (a), Aroma (b), Flavour (c) and Flesh Firmness (d) genotypes Yellow “UFERSA-05” var. ACIDULUS (- $\mathbf{-}$-) and Pele of Sapo "Mabel” (-০-) minimally processed storage in polypropylene tray sealed with PP film by eight days at $8^{\circ} \mathrm{C} \pm 2^{\circ} \mathrm{C}$ for 8 days. Horizontal discontinuous lines indicate the limit of acceptance from the consumer point of view. Serra Talhada-PE, UFRPE/UAST, 2012. 


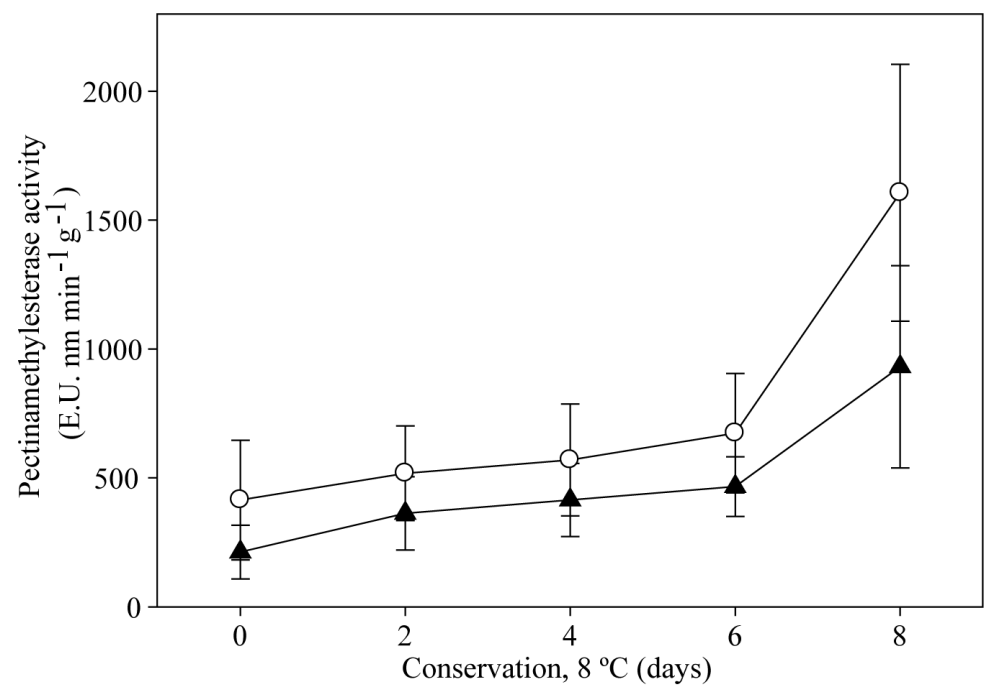

Figure 6. Pectin methylesterase Activity (PME) in Yellow "UFERSA-05" var. ACIDULUS (- $\left.\boldsymbol{\Delta}_{-}\right)$and Pele of Sapo "Mabel” (-o-), minimally processed melon genotypes and storage in polypropylene tray sealed with polypropylene film maintained at $8^{\circ} \mathrm{C} \pm 2^{\circ} \mathrm{C}$ for 8 days. Values are the mean of three replicates and error bars represent the standard deviation. Serra Talhada-PE, UFRPE/UAST, 2012.

processing, featuring high flesh firmness and absence of translucency. However, it showed a low content of total soluble solids and total soluble sugars, and can be consumed as a salad, making it a strong potential for this technology.

\section{Acknowledgements}

The authors thank the Universidade Federal Rural do Pernambuco, the Universidade Federal Rural do Semiárido, CNPq; FACEPE and CAPES for the financial support.

\section{References}

[1] IBGE (2011) Anuário Estatístico do Brasil. IBGE, Rio de Janeiro.

[2] Sales Júnior, R.S., Dantas, F.F., Salviano, A.M. and Nunes, G.H.S. (2006) Qualidade do Melão Exportado pelo porto de Natal-RN. Ciência Rural, 36, 286-289. http://dx.doi.org/10.1590/S0103-84782006000100045

[3] Huber, D.J. (1983) Polyuronide Degradation and Hemicelluloses Modifications in Ripening Tomato Fruit. Journal of American Society of Horticultural Science, 108, 405-409.

[4] Chitarra, M.I.F. and Chitarra, A.B. (2005) Pós-Colheita de Frutas e Hortaliças: Fisiologia e Manuseio. 2nd Edition, UFLA, Lavras, 785.

[5] Portela, S.I. and Cantwell, M.I. (2001) Cutting Blade Sharpness Affects Appearance and Other Quality Attributes of Fresh-cut Cantaloupe Melon. Journal of Food Science, 66, 1265-1270. http://dx.doi.org/10.1111/j.1365-2621.2001.tb15199.x

[6] Prado, M.E.T., Chitarra, A.B. and Rosende, J.U. (2004) Armazenamento de Melão “Orange Flesh” Minimamente Processado sob Atmosfera Modificada. Ciência Agrotecnologia de Lavras-MG, 7 p.

[7] Vieites, R.L., Evangelista, R.M., Lima, L.C., Moraes, M.R. and Neves, L.C. (2007) Qualidade de Melão “Orange Flesh” Minimamente Processado Armazenado sob Atmosfera Modificada. Ciências Agrárias, 28, 409-416. http://dx.doi.org/10.5433/1679-0359.2007v28n3p409

[8] Ukuku, A.D.O., Barib, M.L., Kawamotob, S. and Isshikib, K. (2005) Use of Hydrogen Peroxide in Combination with Nisin, Sodium Lactate and Citric Acid for Reducing Transfer of Bacterial Pathogens from Whole Melon Surfaces to Fresh-Cut Pieces. International Journal of Food Microbiology, 104, 225-233. http://dx.doi.org/10.1016/j.ijfoodmicro.2005.01.016

[9] Aguayo, E., Escalonavh, Artés, F. (2008) Effect of Hot Water Treatment and Various Calcium Salts on Quality of 
Fresh-Cut “Amarillo” Melon. Postharvest Biology and Technology, 47, 397-406. http://dx.doi.org/10.1016/j.postharvbio.2007.08.001

[10] Raybaudi-Massilia, R.M., Mosqueda-Melgar, J. and Martín-Belloso, O. (2008) Edible Alginate-Based Coating as Carrier of Antimicrobials to Improve Shelf-Life and Safety of Fresh-Cut Melon. International Journal of Food Microbiology, 121, 313-327. http://dx.doi.org/10.1016/j.ijfoodmicro.2007.11.010

[11] Aguayo, E., Escalona, V.H. and Artés, F. (2004) Metabolic Behavior and Quality Changes of Whole and Fresh Processed Melon. Journal of Food Science, 4, 148-155.

[12] Chen, C.C. and Paull, R.E. (2001) Fruit Temperature and Crown Removal on the Occurrence of Pineapple Fruit Translucency. Scientia Horticulturae, 88, 85-95. http://dx.doi.org/10.1016/S0304-4238(00)00201-6

[13] Guo, Q., Cheng, L., Wang, J., Che, F., Zhang, P. and Wu, B. (2011) Quality Characteristics of Fresh-Cut “Hami” Melon Treated with 1-Methylcyclopropene. African Journal of Biotechnology, 10, 18200-18209.

[14] Arruda, M.C., Jacomino, A.P., Kulge, R.A. and Azzoline, A. (2003) Temperatura de Armazenamento e tipo de corte para melão Minimamente Processado. Revista Brasileira de Fruticultura, 25, 74-76.

[15] Dische, Z. (1962) General Color Reactions. In: R. L. Whistler and M. L. Wolfram, Eds., 187 Carbohydrate Chemistry. Academic Press, New York, 477-512.

[16] Hultin, H.O., Sun, B. and Bulger, J. (1966) Pectin Methyl Esterase of the Banana. Purification and Properties. Journal of Food Science, 31, 320-327. http://dx.doi.org/10.1111/j.1365-2621.1966.tb00500.x

[17] Souza, P.A., Finger, F.L., Alves, R.E., Puiatti, M., Cecon, P.R. and Menezes, J.B. (2008) Conservação Pós-Colheita de Melão Charentais Tratado com 1-MCP e Armazenado sob Refrigeração e Atmosfera Modificada. Horticultura Brasileira, 26, 464-470. http://dx.doi.org/10.1590/S0102-05362008000400008

[18] Rose, J.K.C., Hadfield, K.A., Labavitch, J.M. and Bennett, A.B. (1998) Temporal Sequence of Cell Wall Disassembly in Rapidly Ripening Melon Fruit. Plant Physiology, 117, 345-361. http://dx.doi.org/10.1104/pp.117.2.345

[19] Hadfield, K.A. and Bennett, A.B. (1998) Polygalacturonases: Many Genes in Search of Function. Plant Physiology, 117, 337-343. http://dx.doi.org/10.1104/pp.117.2.337

[20] Vilas-Boas, E.V.deB., Chitarra, A.B. and Menezes, J. (1998) Modificações dos Componentes de Parede Celular do melão “Orange Flesh” Submetido a Tratamento Pós-Colheita com Cálcio. Brazilian Archives of Biology and Technology, 41, 467-474. http://dx.doi.org/10.1590/S1516-89131998000400011

[21] Bartholomew, R.E., Paull, R.E. and Rohrbach, K.G. (2003) The Pineapple: Botany, Production, End Uses. CABI Publising, London, 301. http://dx.doi.org/10.1079/9780851995038.0000

\section{Abbreviations and Acronyms}

Total Titratable Acidity (TTA);

Total Soluble Solids (TSS);

Loss of Fresh Mass (LFM);

Pectin Methyl Esterase (PME);

Polygalacturonase (PG);

Low Density Polyethylene Film (LDPE);

Polypropylene (PP);

Polyethylene Terephthalate (PET);

Micro Perforated Polypropylene Film (MPP);

Bioriented Polypropylene Film (BPP);

Oriented Polypropylene Film (OPP);

Universidade Federal Rural do Semiárido (UFERSA);

Sodium Hydroxide (NaOH);

Sodium Chloride ( $\mathrm{NaCl})$;

Total Soluble Sugars (TSA). 